\title{
Anther dimorphism and reductional division in Crotalaria spectabilis
}

\author{
Ashutosh Kumar Verma* \\ Central Regional Centre, Botanical Survey of India, 10 Chatam Line, Allahabad 211002, India \\ ${ }^{*}$ Corresponding author, E-mail: simashutosh@rediffmail.com
}

\begin{abstract}
An experiment was carried out to study the anther dimorphism and meiotic behavior of chromosomes in different morphs of anthers in Crotolaria spectabilis. Anthers exhibit dimorphism with respect of their shape, size, surface ornamentation, dehiscence time, pollen size, pollen sterility, pollen germination and meiotic behavior of chromosomes. Meiotic indices, percentage share of different meiotic stages, chiasma frequency per pollen mother cell, chiasma frequency per chromosome, and percentage share of different meiotic anomalies varied with type of anther.
\end{abstract}

Key words: anther dimorphism, Crotolaria spectabilis, heteroanthery, meiotic anomalies.

Abbreviations: PMC, pollen mother cell; SEM, scanning electron microscope.

\section{Introduction}

Angiosperms display unsurpassed diversity in the morphology of reproductive structures, predominantly the stamens. Variation in stamen traits is evident among allied species, between plants, within populations, and also within and between flowers produced by an individual plant (Darwin 1877; Barrett 2002). Among the different types of stamen variation, intra flower polymorphism is a relatively uncommon but taxonomically widespread phenomenon (Marin et al. 2010).

Heteranthery/anther dimorphism, particular form of the foresaid polymorphism, involves the presence of more than one discrete morphs/forms of stamen within the same flower with divergent functions (Vallejo-Marin et al. 2009; Barrett et al. 2010). It occurs in diverse taxonomic groups, and has most likely evolved on numerous independent occasions during the evolution of angiosperms (Barrett et al. 2010).

Correlations between form and function have been demonstrated in many instances including changes in pollinator fauna in closely related species with different floral characteristics such as aquilegia (Whittall et al. 2007), mimulus (Bradshaw et al. 1998), penstemon (Wilson et al. 2006), stylidium (Armbruster et al. 1994), visitation by specialised pollinators and evolutionary shifts from cross- to self-fertilisation. Besides these, it is also associated with absence of floral nectarines (Vallejo-Marin et al. 2009), buzz-pollination (Buchmann 1983), enantiostyly (Jesson, Barrett 2003), presence of staminode and aspects of perianth symmetry, floral orientation (Graham, Barrett 1995) and convergent floral syndrome. Although globally numerous efforts are being made by researchers for understanding of evolution and different dimensions of heteranthery, untill now numerous lacunae are available. Among these lacunae, unavailability of proper information regarding "anther dimorphism and associated meiotic behaviour of chromosome" is an important one. Hence, male gametogenesis related to the anthers, and gametes determines the faith of progeny in sexually reproducing plants so there is also an urgent need for the exploration of this aspect of heteranthery.

Crotalaria L. belongs to the tribe Crotalarieae, having anther dimorphism, comprising around 600 herbaceous and shrub species distributed in the tropics and subtropics (Polhill 1982). In India, this genus is represented by 81 species of which 27 are endemic and 15 species are listed in red data book of India (Nyer, Sastry 1987). Crotolaria spectabilis Roth, a native to the Indo-Malaysian, is a well known and widely distributed species comprising of two whorls of stamens $(5+5)$ with differential growth and dimorphic anthers. This species grown in western countries as a fodder plant, green manure, as its root nodules fix atmospheric nitrogen.

In India, extracts of $C$. spectabilis are used in the treatment of impetigo, scabies, and intestinal worms (http://eol.org/pages/694556/overview). Numerous efforts were made to understand the role of anther dimorphism in pollination and reproductive biology of the foresaid taxon but anther dimorphism and associated meiotic behaviour of chromosome remains also untouched in this taxon like other taxa. Therefore, the aim of the present study was to analyse the possible role of anther dimorphism in reproductive biology of C. spectabilis. 


\section{Materials and methods}

For the study of reductional division, floral buds of $C$. spectabilis were collected from its population growing in Aacharya Jagdish Chandra Bose Indian Botanic Garden, Howrah and fixed in Carnoys fluid between 5:45 and 6:10 (December, 2015) for $24 \mathrm{~h}$ and further stored in $100 \%$ ethanol. Large and small sized anthers excised from suitable floral buds, were squashed separately in $2 \%$ acetocarmine and considered meiotic parameters were recorded. Floral buds approaching maturity were used for the study of anther and pollen characteristics. Stainability of pollen grain with acetocarmine was used as an index for determining pollen sterility. The pollen germination percentage was evaluated using the sucrose solution $(30 \%)$ method. The Meiotic Index, MI (\%) $=100$ (No. of normal tetrads/total meiocytes), was calculated from more than 1200 meiocytes from each type of anther. The data on all considered parameters were recorded in replicates and then statistically analysed using SPSS software. For scanning electron microscopic (SEM) study, anthers and pollen grains were properly dried and mounted directly on adhesive tape. Subsequently, gold coating was made to produce material for SEM study. Observations were made with a QUANTO 200, FEI 500 Scanning Electron Microscope and scanning electron micrographs were taken.

\section{Results and discussion}

Anthers of C. spectabilis exhibit dimorphism with respect of their shape, size, surface ornamentation, dehiscence time, pollen size, pollen sterility and pollen germination (Table 1). Large elongated anthers contained ridged granular and small rounded anthers contained wormiform and spiral ridged surface ornamentation (Fig. $1 \mathrm{~A}$ and $\mathrm{B}, \mathrm{F}$ and $\mathrm{G}$ ). Large anthers dehisced at early hours of the day $(<8: 30)$ and small anthers at late hours $(>10: 45)$. This confers staggered presentation (asynchronous) of pollen in C. spectabilis. Staggered pollen presentation is either achieved by altering time of anthesis within an inflorescence or anther dehiscence within a flower coupled with gradual releasing of pollen grain from anther pore (Harder, Thomson 1989). According to Sarala et al. (1999) it reduces the risk of pollen removal by an individual pollinator during a single visit and favours dispersal of pollen grains to more pollinators and subsequently to several poles apart stigmas. In the Harder and Thomson (1989) model, synchronous pollen presentation was linked with low pollinator visit rates and staggered with high pollinator visitation rate.

Pollen grains of both types of anthers were tricolporate, prolate and semi-angular (Fig. $1 \mathrm{C}$ and D, I and J). The tectum was microperforate and the apocolpium ornamentation was more or less the same as the mesocolpium area (Fig. $1 \mathrm{E}$ and J). Exine stratification was almost identical. Our findings with respect to surface appearance of pollen grains are consistent with the findings of Lin and Huang (1999) on Crotalaria species and contrary with the findings of Pacini and Bellani (1986) and Fujiki et al. (1997) in Lagerstroemia indica, and Commelina communis, respectively where dimorphic or polymorphic pollen from different types of anthers was observed.

Pollen mother cellc (PMC) of both types of anthers shared almost equal dimensions and revealed eight ring bivalents $(2 \mathrm{n}=16)$ at dikinesis and metaphase-I, which was in agreement with findings of earlier workers (Atchison 1951; Datta, Mondal 1969; Boulter et al. 1970; Verma et al. 1980; Bairgajan, Patnaik 1989; Almada et al. 2006) (Table 1, Fig. $2 \mathrm{~A}$ to C). Meiotic indices and percentage share of different meiotic stages varied with type of anthers (Table 2), although belonged to same floral bud. Higher meiotic indices for elongated anther (16.71) and lower for rounded anther (9.02) are probably responsible for variation in size of pollen sac and thus per unit production of pollen grains.

Anther type dependent chiasma frequency per PMC and per chromosome was observed and higher amplitude was noted for elongated anther (Table 2). This asynchrony in the behavior of chromosome attributes may be due to presence of two separate genetic controls for the same (Koul et al. 2012). Although variation was found in chiasm frequency of both type of anthers, in both cases it was adequately high. It has been suggested that excess of stability caused by selfing (as in our experimental plant) should be compensated by higher rate of recombination whereas in out crossing species the flexibility is achieved through the repeated reshuffling of genetic material following the mating with unrelated individuals (Zarchi et al. 1972).

In both type of anthers in trace proportions meiotic anomalies were also observed and their frequency was found higher in small anther (Table 2). Univalents, stray, precautious movement, bridge and micronuclei were recorded as most common anomalies and the former

Table 1. Anther and pollen characteristics of Crotolaria spectabilis. ns, $p>0.05 ;{ }^{*}, p<0.05 ;{ }^{* *}, p<0.01$

\begin{tabular}{lcc|}
\hline Trait & Large anther & Small anther \\
\hline Anther length $(\mathrm{mm})$ & $03.20 \pm 0.12$ & $0.092 \pm 0.001^{* *}$ \\
\hline Anther width $(\mathrm{mm})$ & $01.50 \pm 0.10$ & $0.093 \pm 0.001^{* *}$ \\
\hline PMC length $(\mu \mathrm{m})$ & $21.09 \pm 1.11$ & $19.99 \pm 0.74^{*}$ \\
\hline PMC width $(\mu \mathrm{m})$ & $17.76 \pm 1.11$ & $17.76 \pm 1.11 \mathrm{~ns}$ \\
\hline $\begin{array}{l}\text { Pollen length }(\mu \mathrm{m}) \\
\text { Pollen width }(\mu \mathrm{m})\end{array}$ & $38.08 \pm 2.07$ & $34.00 \pm 2.26^{*}$ \\
\hline $\begin{array}{l}\text { Length of surface micro- } \\
\text { perforations of pollen }\end{array}$ & $0.36 \pm 0.037$ & $0.36 \pm 0.03 \mathrm{~ns}$ \\
grains ( $\mu \mathrm{m})$ & & \\
$\begin{array}{l}\text { Width of surface micro- } \\
\text { perforations of pollen }\end{array}$ & $0.29 \pm 0.02$ & $0.25 \pm 0.04^{*}$ \\
grains $(\mu \mathrm{m})$ & & \\
Pollen sterility $(\%)$ & $26.31 \pm 0.78$ & $28.02 \pm 2.27^{*}$ \\
\hline $\begin{array}{l}\text { Pollen germination }(\%) \\
54.87 \pm 5.10\end{array}$ & $46.47 \pm 6.07^{* *}$
\end{tabular}



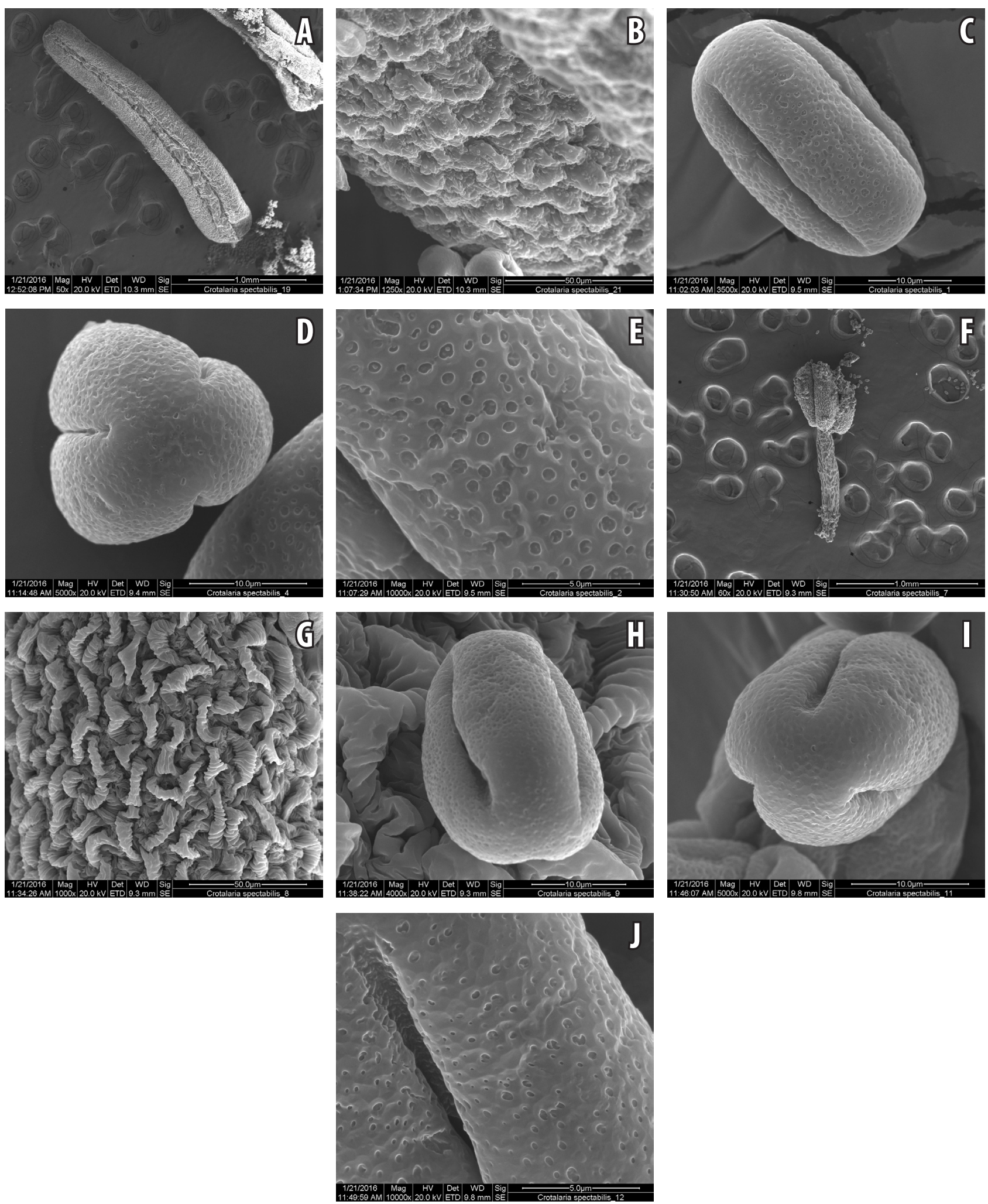

Fig. 1. Scanning electron micrographs of large anther (A), surface view of large anther (B), pollen grain of large anther (C), polar view of pollen grain of large anther (D), surface view of pollen grain of large anther showing microperforated ornamentation (E), small anther $(F)$, surface view of small anther $(\mathrm{G})$, pollen grain of small anther $(\mathrm{H})$, polar view of pollen grain of small anther $(\mathrm{I})$, surface view of pollen grain of small anther showing microperforated ornamentation (J) of Crotolaria spectabilis. 

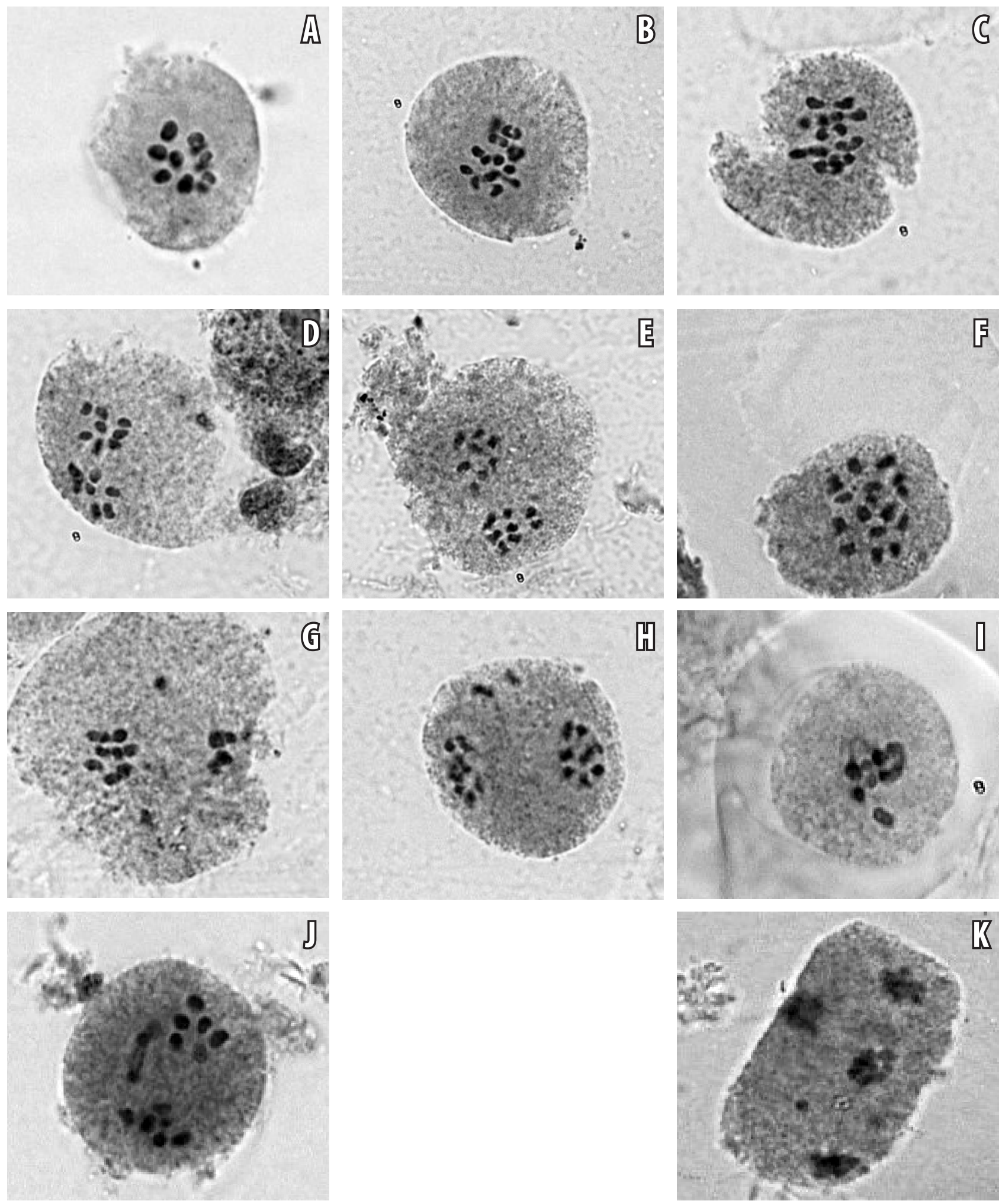

Fig. 2. Meiotic stages in anthers of Crotolaria spectabilis. Prophase-I (8 bivalent $2 \mathrm{n}=16)(\mathrm{A}, \mathrm{B}, \mathrm{C})$; anaphase-I (D, E); univalents (F); Lagard $(\mathrm{G})$; stray $(\mathrm{H})$; precautious movement $(\mathrm{I})$; bridge $(\mathrm{J})$; micronuclei $(\mathrm{K})$.

three showed higher amplitude in small anther (Fig. F to $\mathrm{K})$. Formation of univalents is a result of asynapsis and desynapsis which are either removed or indiscriminately transmitted to progeny cells, resulting a numarically imbalanced gametes or aneuploids in the offspring (Cai et al. 2007). In addition, univalents may undergo misdivision, 
Table 2. Meiotic behavior of dimorphic anthers of Crotolaria spectabilis. ns, $p>0.05 ;{ }^{*}, p<0.05 ;^{* *}, p<0.01$

\begin{tabular}{|c|c|c|}
\hline Traits & Large anther & Small anther \\
\hline Total number of PMCs & 1287 & 1374 \\
\hline Meiotic index & 16.71 & $9.02^{\star *}$ \\
\hline $\begin{array}{l}\text { Chiasma frequency/ } \\
\text { PMC }\end{array}$ & 18.92 & $12.40^{* *}$ \\
\hline $\begin{array}{l}\text { Chiasma frequency/ } \\
\text { chromosome }\end{array}$ & 1.18 & $0.46^{* *}$ \\
\hline \multicolumn{3}{|c|}{ PMCs in (\%) } \\
\hline Prophase-I & 20.47 & $12.90^{* *}$ \\
\hline Metaphase-I & 14.88 & $07.26^{\star *}$ \\
\hline Anaphase-I & 09.77 & $04.84^{\star *}$ \\
\hline Telophase-I & 09.30 & $10.48^{*}$ \\
\hline Prophase-II & 07.44 & $07.26 \mathrm{~ns}$ \\
\hline Metaphase-II & 10.23 & $20.97^{\star *}$ \\
\hline Anaphase-II & 06.98 & $12.90^{* *}$ \\
\hline Telophase-II & 20.93 & $23.38^{*}$ \\
\hline \multicolumn{3}{|c|}{ Meiotic anomalies (\%) } \\
\hline Univalents & 17.65 & $34.43^{\star *}$ \\
\hline Stray & 5.88 & $06.56 \mathrm{~ns}$ \\
\hline Bridge & 03.28 & $14.70^{* *}$ \\
\hline Precautious movement & 23.53 & $29.51^{\star}$ \\
\hline Micronuclei & 20.59 & $19.67 \mathrm{~ns}$ \\
\hline Others & 17.65 & $06.56^{* *}$ \\
\hline
\end{tabular}

such as transverse division, to produce telocentric, acrocentric and isochromosomes (Sears 1952; Friebe et al. 2005). Univalents not only interfere with the completion of meiosis, but also survival of the individual through sexual propagation is greatly impaired (Soost 1951). The presence of such univalent chromosomes resulted in a decrease in chiasma frequency and in turn considerably lowers gametic fertility (Kumar et al. 2013). Detrimental effects of univalents on faith of meiosis and pollen fertility have also been documented by several workers (Maity, Datta 2009a; Maity, Datta 2009b; Datta et al. 2010; Goyal, Khan 2010). The occurrence of univalent chromosomes in diploid plants has been attributed to the hybrid constitution of the genome (Stebbins, Pun 1953; Leggett 1998; Kumar et al. 2012).

Precocious chromosome migration to the poles may have resulted from spindle dysfunction or precocious chiasma terminalisation at diakinesis or metaphase-I (Kumar, Rai 2007). Stray seems to be possibly caused by spindle dysfunction and clumping of chromosomes (Bhat et al. 2007). The formation of anaphasic bridges might be due to the failure of chiasmata in a bivalent to terminalise and the chromosome gets stretched between the poles (Saylor, Smith 1966), due to unequal exchange or dicentric chromosomes and paracentric inversions (Sinha, Godward 1972) etc. Observed micronuclei, tiny extranuclear bodies, may be due to the association of fragments and lagging chromosomes, failed to reach the poles and becoming included in the daughter nuclei (Sedelnikova et al. 2007; Fenech et al. 2011; Luzhna et al. 2013). Acentric chromatid/chromosome fragments usually originate after extensive DNA damage such as DNA double-strand breaks, which if misrepaired result in asymmetrical chromosome rearrangements and exchanges. Whole chromatids or chromosomes in micronuclei are formed due to deficiencies in chromosome segregation during anaphase, usually caused by mitotic spindle failure, kinetochore damage, centromeric DNA hypomethylation, and defects in the cell cycle control system (Mateuca et al. 2006).

High pollen sterlity and low pollen viability could be associated to the observed meiotic irregularities, since they have potential for chromosome number alteration, or to post-meiotic events. Possibly, many microspores having an irregular chromosome number became abortive. A number of studies have shown that inbreeding depression can contribute to pollen stertility (Krebs, Hancock 1990; Willis 1993; Husband, Schemske 1996; Goodwillie 2000). In addition, there are a number of non-genetic causes of pollen un-viability, including pollen age and physical factors such as temperature and humidity (Kelly et al. 2002). Still, considering that these species produce large amounts of seeds, both in natural populations and under cultivation, such low viability must be compensated by the large number of pollen grains.

In conclusion, findings of the present investigation indicate that heteroanthery, an evolutionary important phenomenon, is not only limited to morphological variation of anthers but involves cytogenetic level variation in different morphs of anthers. As any cytogenetical change during micro-sporogenesis process determines faith of progeny of any plant, hence, there is need for more concerted efforts to explore the developmental aspect of anther dimorphism. That will definitely praise new insight to understand evolutionary aspects of economically important genera like Crotalaria.

\section{Acknowledgements}

The corresponding author is grateful to The Director, Botanical Survey of India; Head of Office, Central Botanical Laboratory and Head of Office, AJC Bose Indian Botanic Garden, Howrah, for their kind support and providing necessary facilities during the course of present investigation.

\section{References}

Almada R.D., Daviña J.R., Seijo J.G. 2006. Karyotype analysis and chromosome evolution in southernmost South American species of Crotalaria (Leguminosae). Bot. J. Linn. Soc. 150: 329-341.

Armbruster W.S., Edwards M.E., Debevec E.M. 1994. Floral character displacement generates assemblage structure of Western-Australian trigger plants (Stylidium). Ecology 75: 315-329. 
Atchinson E. 1950. Studies in the Leguminosae V. cytological observations on Crotalaria. J. Elisha Mitchell Sci. Soc. 66: 7075.

Bairigajan G.C., Patnaik S.N. 1989. Chromosomal evolution in Fabaceae. Cytologia 54: 51-64.

Barrett S.C.H. 2002. The evolution of plant sexual diversity. Nature Rev. Genet. 3: 274-284.

Barrett S.C.H. 2010. Darwin's legacy: the forms, function and sexual diversity of flowers. Phil. Trans. Royal Soc. B Biol. Sci. 365: 351-368.

Bhat T.A., Sharma M., Anis M. 2007. Comparative analysis of meiotic aberrations induced by diethylsulphate and sodium azide in broad bean (Vicia faba L.). Asian. J. Plant. Sci. 6: 1051-1057.

Bouter D., Derbyshire E., Frahm-Leliveld J. A., Polhill R. M. 1970. Observations on the cytology and seed proteins of various African species of Crotalaria L. (Leguminosae). New Phytol. 69: 117-131.

Bradshaw H.D., Otto K.G., Frewen B.E., McKay J.K., Schemske D.W. 1998. Quantitative trait loci affecting differences in floral morphology between two species of monkeyflower (Mimulus). Genetics 149: 367-382.

Buchmann S.L. 1983. Buzz pollination in angiosperms. In: Jones C.E., Little R.J. (eds) Handbook of Experimental Pollination Biology. New York,NY, USA: Scientific and Academic Editions, 73-113.

Cai X., Xu S.S. 2007. Meiosis driven genome variation in plants. Curr. Genom. 8: 151-161.

Darwin C. 1877. The Different Forms of Flowers on Plants of the Same Species. John Murray, London.

Datta A.K., Mukherjee S., Saha A., Das A. 2010. Seasonal influence on the chromosome behaviour of diploid (Solanum nigrum L.) and hexaploid (S. americanum Mill.) species of Solanum. Asian J. Exp. Biol. Sci. 1: 193-196.

Datta R. M., Mondal M. 1969. New cytotypes in a species of Crotalaria and chromosome number in certain other species. Sci. Cult. 35: 154-155.

Fenech M. 2011. Micronuclei and their association with sperm abnormalities, infertility, pregnancy loss, pre-eclampsia and intra-uterine growth restriction in humans. Mutagenesis 26: 63-67.

Friebe B., Zhang P., Linc G., Gill B.S. 2005. Robertsonian translocations in wheat arise by centric misdivision of univalents at ana-phase I and rejoining of broken centromeres during interkinesis of meiosis II. Cytogen. Genome Res. 109: 293-297.

Fujuki T., Sunaakawa M., Morita Y., Miyoshi N. 1997. Pollen morphology of Commelina communis (Commelinaceae). Jap. J. Palynol. 43: 31-35.

Goodwillie C. 2000. Inbreeding depression and mating systems in two species of Linanthus (Polemoniaceae). Heredity 84: 283293.

Goyal S., Khan S. 2010. Cytology of induced morphological mutants in Vigna mungo (L.) Hepper. Egypt. J. Biol. 12: 81-85.

Graham S.W., Barrett S.C.H. 1995. Phylogenetic systematics of Pontederiales: implications for breeding-system evolution. In: Rudall P.J., Cribb P.J., Cutler D.F., Humphries C.J. (eds) Monocotyledons: Systematic and Evolution. Kew, UK: Royal Botanical Gardens, 415-441.

Harder L.D., Thomson J.D. 1989. Evolutionary options for maximizing pollen dispersal of animal-pollinated plants. Am. Nat. 133: 323-344
Husband B. C., Schemske D. W. 1996. Evolution of the magnitude and timing of inbreeding depression in plants. Evolution 50: 54-70.

Jesson L.K., Barrett S.C.H. 2003. The comparative biology of mirror-image flowers. Int. J. Plant Sci. 164: S237-S249.

Kelly J. K., Rasch A., Kalisz S. 2002. A method to estimate pollen viability from pollen size variation. Am. J. Bot. 89: 1021-1023.

Koul K. K., Nagpal R. 2002. Sex incidences of chiasmata variation in respect of position, distribution and frequency in some important legumes and grasses. Caryologia 55: 251-261

Krebs S. L., Hancock J. F. 1990. Early-acting inbreeding depression and reproductive success in the high bush blueberry, Vaccinium corymbosum. Theor. Appl. Genet. 79: 825-832.

Kumar G., Rai P.K. 2007. EMS induced karyomorphological variations in maize (Zea mays L.) inbreds. Turk. J. Biol. 31: 187-195.

Kumar P., Singhal V.K. 2013. Reduction in chiasma frequency and pollen fertility due to multiple chromosomal associations and univalents in Saxifraga diversifolia from alpine regions of northwest Himalayas (India). Caryologia 66: 120-127.

Kumar P., Singhal V.K., Kaur D. 2012. Impaired male meiosis due to irregular synapsis coupled with cytomixis in a new diploid cytotype of Dianthus angulatus (Caryophyllaceae) from Indian cold deserts. Folia Geobot. 47: 59-68.

Leggett J.M. 1998. Chromsosmes and genomic relationship between the diploid species of Avena strigosa and A. eriantha and the tetraploid A. macroccana. Heredity 80: 316-363.

Lin H.W., Huang T.C. 1999. A palynological study of genus Crotalaria L. (Leguminosae) in Taiwan. Taiwania 44: 384-403.

Luzhna L., Kathiria P, Kovalchuk O. 2013 Micronuclei in genotoxicity assessment: from genetics to epigenetics and beyond. Front. Genet. 4: 131.

Maity S., Datta A.K. 2009a. Meiosis in nine species of Jute (Corchorus). Indian J Sci. Technol. 2: 27-29.

Maity S., Datta A.K. 2009b. Spontaneous desynapsis in Corchorus fascicularis Lamk. (Family: Tiliaceae). Indian J. Sci. Technol. 2: 34-36.

Marın M.V., Da Silva E. M., Sargent R.D., Barrett S.C.H. 2010. Trait correlates and functional significance of heteranthery in flowering plants. New Phytol. 188: 418-425.

Mateuca R., Lombaert N., Aka P. V., Decordier I., Kirsch-Volders M. 2006. Chromosomal changes: induction, detection methods and applicability in human biomonitoring. Biochimie 88: 1515-1531.

Nayar M.P., Sastry A.R.K. 1987. Red Databook of Indian Plants. Vol. 1. Botanical Survey of India, Culcutta.

Pacini E., Bellani L.M. 1986. Lagerstroemia indica L. pollen: form and function. In: Blackmore S., Ferguson I.K. (eds) Pollen and Spore: Form and function. Academic Press. London et al.

Polhill R.M. 1982. Crotalaria L. in Africa and Medagascar. CRC Press, Florida.

Polhill R.M. 1968. Miscellaneus notes on African species of Crotalaria L.: II. Kew Bull. 22: 169-338.

Sarala B.S, Lokesha R., Vasudeva R. 1999. Anther dimorphism, differential anther dehiscence, pollen viability, and pollination success in Caesalpinia pulcherrima L. (Fabaaece). Curr. Sci. 76: 1490-1494.

Saylor L.G., Smith B.N. 1966. Meiotic irregularities in species of interspecific hybrids in Pisum. Am. J. Bot. 53: 453-468.

Sears E.R. 1952. Misdivision of univalents in common wheat. Chromosoma 4: 535-550.

Sedelnikova O. A., Nakamura A., Kovalchuk O., Koturbash I., 
Mitchell S., Marino S.A., Brenner D.J., Bonner W.M. 2007. DNA double-strand breaks form in bystander cells after microbeam irradiation of three-dimensional human tissue models. Cancer Res. 67: 4295-4302.

Sinha S.S.N., Godward M.B.E. 1972. Radiation studies in Lens culinaris. Meiosis: abnormalities induced due to gamma radiation and its consequences. Cytologia 37:685-695.

Soost RK. 1951. Comparative cytology and genetics of asynaptic mutants in Lycopersicon eseulentum Mill. Genetics 36: 410434.

Stebbins G.L., Pun F.T. 1953. Artificial and natural hybrids in the Gramineae, tribe Hordeae. V. Diploid hybrids of Agropyron. Am. J. Bot. 40: 444-449.

Vallejo-Marı'n M., Manson J.S., Thomson J.D., Barrett S.C.H. 2009. Division of labour within flowers: heteranthery, a floral strategy to reconcile contrasting pollen fates. J. Evol. Biol. 22:
$828-839$.

Verma R.C., Raina S.N. 1980. Cytogenetics of Crotalaria. II. Male meiosis in 8 species of Crotalaria. Cytologia 45: 297-306.

Whittall J.B., Hodges S.A. 2007. Pollinator shifts drive increasingly long nectar spurs in columbine flowers. Nature 447: 706-712.

Willis J.H. 1993. Effects of different levels of inbreeding on fitness components in Mimulus guttatus. Evolution 47: 864-876.

Wilson P., Castellanos M.C., Wolfe A.D., Thomson J.D. 2006. Shifts between bee and bird pollination in Penstemons. In NM Waser N.M., Ollerton J. (eds) Plant-pollinator Interactions: from Specialization to Generalization. University of Chicago Press, Chicago, pp. 47-68.

Zarchi Y., Simchen G., Hillel J., Schaap T. 1972. Chiasmata and breeding system in wild populations of diploid wheats. Chromosoma 38: 77-94. 